\title{
Dr Richard Herbert Lindenbaum, FRCP, 9.7.33-10.4.92
}



As I first met Dick Lindenbaum in Oxford in 1978, and worked with him as a close colleague, indeed his closest colleague, from 1980 to 1990 , I can only write from experience of his last decade. I am indebted to Professor Bobrow, his closest colleague of an earlier decade and the author of his obituary in the $B M \mathcal{A}$, for earlier information and to Dr Oliver Sacks, who continued a school friendship, for the contribution on his earlier life he has allowed me to append, and which is an elaboration on the funeral oration he delivered.

Dick was one of the last of the general clinical geneticists whose knowledge covered almost the whole field of genetic disease. He started with a solid background in paediatrics, including experience of neonates under Professor Tizard, an extensive knowledge of a literature covering many languages and centuries, and an aptitude for mathematics. (He was one of the few adults to master the Rubik cube.) His patient attention to symptoms, to be followed by an exacting physical examination, later recorded in very detailed notes accompanied by photographs of the highest standard, soon gave him an unchallenged reputation both as a diagnostician and a safe doctor and an adviser to other clinical geneticists. His knowledge was particularly deep on the chromosomal disorders, in which he was aided by having had Professor Bobrow as a colleague; he had a continuing interest in examining chromosomes at the microscope and a deep knowledge of normal and variant dermatoglyphs of both hands and feet. He took equal care to see that his opinions were understood by even the most uninformed patients, and that any necessary tests were done by the most expert laboratories. He once made an overnight delivery of amniotic fluid to Paris.
Although his case notes and well documented photographs are an impressive record, and will be a source of accurate data for future generations of patients, and of inspiration to a future generation of doctors, he probably exerted an even greater influence from his willingness to be consulted at any time by phone, and to go anywhere to see any patient. $\mathrm{He}$ always attended terminations of pregnancy if diagnostic procedures were indicated which could not, or, according to his exacting standards, should not, await working hours.

His influence through publication was extensive, even if not yet adequately appreciated. His major contribution was undoubtedly the finding of a translocation in a girl referred with muscular dystrophy. This paper, although preceded by a similar report from Belgium, was very detailed and clearly emphasised the significance of the result and the need to define the junction to define the causal lesion. These cases led to attempts to do this in Toronto, Edinburgh, Oxford, and elsewhere. Although these approaches were later eclipsed by Kunkel's success in defining the missing segment in an affected boy, they led to the first sequencing of a translocation junction in a vertebrate in Toronto in the Belgian case and, later, to sequencing the join in his case in Oxford. In both, the cut and join event was associated with losses of short segments.

The significance of the visible deficiency in the boy studied by Kunkel was greatly strengthened by his earlier finding in girls, while the discoverers of the first two cases set a welcome example in making all the cell lines widely available and, with their laboratory colleagues, they maintained collaborations unclouded by claims of priority. Dick continued to communicate with the original patient who lived on the coast and who during the last years of her short life took an active interest in the contribution she knew she was making to research: she even received annotated photostats of Southern blots.

Another case, as yet unpublished, and only recently fully resolved, was that of a woman with a normal phenotype both of whose fourth chromosomes were maternal in origin. This was extensively investigated with the late Peter Cook, one of many largely unpublished collaborations whose documentation, mostly buried in various notes, will continue to emerge for decades and startle those who knew either man by the clarity and depth of their discussions and, I suspect, the success of their predictions which could not be fully validated within the
A brief notice appeared journal. 
technical resources of their tragically shortened lives.

Although he was less interested in disorders without static visual signs he established an extensive series of almost 300 families with Huntington's chorea, mostly well documented, in the Oxford Region. In tuberous sclerosis, a condition more in line with his expertise in shapes and blemishes, he increased the number of diagnoses of tuberous sclerosis almost tenfold in as many years in association with Mrs Ann Hunt who founded the parents' group. He always gave great support to such groups.

The absolute priority he gave to patients left little time for any administrative activities, and if his colleagues sometimes despaired of the extremes to which this could be carried - he seemed to regard even opening a letter with the tell tale postmark of our local administration as inconsistent with the Hippocratic Oath - the problems this created were outweighed by the example of timeless intensity with which he applied his extraordinary gifts to patients and their problems.

Outside medicine his modesty concealed the depth of his interests. He had an extensive knowledge of languages, speaking Hungarian, demotic Greek, Serbo-Croatian, and Bulgarian, the fruits of walking holidays while a student and junior doctor, as well as enthusiastic fluency in German and the major Romance languages: he even knew enough Finnish to discuss the Lappish number system with a sledge driver while his hosts took him shooting, a sport he was unlikely to appreciate. He was unusually well informed on art and history, especially the relation of language to European migrations. His agnosticism was no bar to an informed appreciation of monastic architecture.

He has left behind a substantial library, a mass of unpublished work, many well documented slides, and a few incomplete papers which await completion. The original intention of his immediate colleagues was to plant a lindenbaum, or lime tree, near the DNA laboratory, whose development he did so much to encourage. However, in view of uncertainty over its future location this intention has expanded to a copse at the Churchill Hospital where he worked, occasionally lived, and died. Any individual or organisation wishing to contribute a tree should forward $£ 25$ or $\$ 50$ to 'The Lindenbaum Account' care of Dr Jane Hurst, The Churchill Hospital, Oxford.

J H EDWARDS

I first met Dick in 1944, when we entered St Paul's School as Junior Foundation Scholars, and found ourselves on the same day in the same class the youngest there by a couple of years, and sharing the same birthday, 9 July. We were instantly dubbed 'the twins', and this was a sense we too had at once, and which deepened over the years as we became close friends, shared many interests, and found our paths in life strangely parallel. Our fathers, we found, both General Practitioners, had also been friends for many years, and this gave a 'hereditary' as well as a personal quality to our friendship.

Both of us, at 11 , had already developed a passion for science, especially biology, and this was to bloom a couple of years later when we came under the influence of a wonderful biology teacher, the late S R B Pask, and were joined by two other boys, Eric Korn and Jonathan Miller, who had similar interests and also became close friends. All of us were fascinated by The modern synthesis (Huxley's book had just come out) and perhaps Dick's later work in genetics was prefigured in this, although none of us, at 14 , knew what we wanted to do. All of us were passionate readers, with an appetite for novels and poetry, for art no less than science, and all of us, perhaps, wondered about literary careers too. This doubleness was especially striking in Dick, who was at once the most mathematical among us, and the most tenderly, even unbearably, drawn to human plights and their exploration. This was finally reconciled, in Dick, by his unique career as a clinical geneticist, his combining of an enormous sensitivity towards patients and their families with the most fundamental scientific analysis.

Again, Dick was a romantic, through and through. He wrote remarkable poetry as a young man, and continued to write poetry throughout his life-only a very little, too little, of this was ever published, because of his modesty, his shyness. He had a passion for languages, at once romantic and linguistic, and was fluent in a great many of them. He was a man of encyclopaedic reading and knowledge. $\mathrm{He}$ was a long distance runner, and a sometimes reckless mountain climber and screes runner, as a young man, and remained addicted to long solitary walks throughout his life.

Dick and I got our scholarships to Oxford at the same time, and it was easy to be close then-he at University, I at Queens, were just on opposite sides of the High; easy too to be close as medical students, when our hospitals were only a stone's throw away in London. Our paths diverged, professionally, when I came to the United States in 1960, but we continued close friends, writing, seeing each other whenever we could-the special feeling of twinship remained to the end, and with his death I feel that I have lost my true twin.

OLIVER SACKS 